фропатией и СД типа 2 целесообразно назначать аторвастатин (10-40 мг/сут) для достижения целевого уровня показателей липидного спектра крови, коррекции дислипидемии, снижения проатерогенной направленности.

Ключевые слова: артериальная гипертензия; диабетическая нефропатия; сахарный диабет типа 2; аторвастатин; липидный спектр крови.

\title{
EFFECTIVENESS OF ATORVASTATIN THERAPY \\ IN PATIENTS WITH ARTERIAL HYPERTENSION, DIABETIC NEPHROPATHY AND DIABETES MELLITUS TYPE 2
}

\section{O. M. Chernatska1, T. S. Mazur ${ }^{1}$, N. V. Demikhova ${ }^{1}$, O. M. Vlasenko², T. M. Rudenko ${ }^{1}$, I. O. Forkert ${ }^{1}$ (Sumy, Kharkiv; Ukraine)}

${ }^{1}$ Sumy State University; ${ }^{2}$ Kharkiv medical academy of postgraduate education

The actual problem of internal medicine is the managemen of patients with comorbid pathology. Arterial hypertension (AH) is determined in about quarter of the population in the world. Moreover, the coexistence of $\mathrm{AH}$ and type 2 diabetes mellitus (DM) connected with the increased risk of cardiovascular complications (CVC) compared with patients with $\mathrm{AH}$. In principle dyslipidemia is the common link between $\mathrm{AH}$ and type $2 \mathrm{DM}$, which need the correction. No doubt that reduction of atherogenic and increase of anti atherogenic lipoproteins is necessary for persons with comorbid pathology. The objective of our study was the assessment of atorvastatin treatment in patients with AH, diabetic nephropathy and type 2 DM. We obtained 96 patients with AH, diabetic nephropathy and type 2 DM (I group), 25 persons with AH (II group), 15 conditionally healthy individuals. Persons had CVC in the past. For patients from the I and II group CVC were defined accordingly $(4,97 \pm$ $0,20)$ years and $(4,10 \pm 0,05)$ years ago $(\mathrm{P}=0,0291)$. The duration of $\mathrm{AH}$ is $(8,1 \pm 0,2)$ years for the I group and $(8,90 \pm 0,13)$ years for the II group. The levels of lipid profile spectrum were determined according to the methods of W. T. Friedewald. The results of investigation were analyzed with the help of Microsoft Excel 2016. Correction of lipid profile spectrum is the important part of multipurpose treatment for persons with coexistent pathology. All patients were treated by atorvastatin (10-40 mg/day) during 6 months in a complex therapy. The target levels of general cholesterol during 6 months were presented in 30 persons $(31.91 \%)$, low density lipoproteids - in 10 persons $(10.64 \%)$, high density lipoproteids - in 26 persons (27.66 \%), triglycerides - in 34 persons $(36.17 \%)$ among patients with $\mathrm{AH}$, diabetic nephropathy and type $2 \mathrm{DM}$. In conclusion, it is advisable to prescribe atorvastatin (10-40 mg/day) for correction of dyslipidemia, reduction of proatherogenic orientation, prevention of atherosclerotic process manifestation and cardiovascular complications in patients with $\mathrm{AH}$ with diabetic nephropathy and type 2 diabetes mellitus.

Key words: arterial hypertension; diabetic nephropathy; type 2 diabetes mellitus; atorvastatin; lipid profile.

\section{ДІАГНОСТИКА ПНЕВМОНІЇ У НЕДОНОШЕНИХ ДІТЕЙ ГРУДНОГО ТА РАННЬОГО ВІКУ В ПРАКТИЦІ СІМЕЙНОГО ЛІКАРЯ}

Кафедра пропедевтики дитячих захворювань і догляду за хворими дітьми (зав. - проф. Л. М. Булат) Вінницького національного медичного університету ім. М. І. Пирогова $<$ olysunets@gmail.com>

Оскільки патологія дихальної системи посідає провідне місие у структурі захворюваності дитячого віку, пошук нових теоретичних даних та поширення клінічного досвіду сприяє фаховому зростанню лікарів-педіатрів та лікарів загальної практики сімейної медицини. Дуже важливим є налагодження лікарського супроводу та збереження професійної пильності щуодо спостереження за дітьми грудного і раннього віку. Особливої уваги потребують передчасно народжені діти, оскільки часто симптоми морфофунк- 
ціональної незрілості і неврологічних порушень не дозволяють вчасно визначитися із соматичною патологією, щуо призводить до втрати часу $і$ зволікання з встановленням клінічного діагнозу. Разом з тим частка дітей, народжених передчасно, залишається у межах 5 \%, шчо вимагає адекватної та коректної тактики втручання лікарів первинного контакту. Поширюючи досвід спостереження та лікування немовлят і дітей раннього віку, автори прагнули визначити характерні ознаки перебігу ичих періодів у передчасно народжених дітей, з'ясувати найбільш вагомі симптоми та анамнестичні дані, асоиійовані маніфестацією інфекиійно-запального ураження легень та визначити їхні діагностичні коефіцієнти (ДК) і загальну інформативність вищевказаних клінічних детермінант (j). Було проаналізовано дані спостереження за недоношеними дітьми основної групи з верифікованим, відповідно до вітчизняних стандартів діагностики $i$ лікування, паренхіматозним ураженням легень та контрольної групи. У статті описано клініко-анамнестичні особливості перебігу пневмонії у недоношених грудного $i$ раннього віку з терміном гестації $\geq 32$ тиж. Визначено важливі клінічні детермінанти, щуо сприяють верифікації діагнозу сімейним лікарем. Вказано на зміни в органах $і$ системах, які асоціюються з розвитком пневмонії у недоношених. Найважливіші клінічні детермінанти розвитку пневмонії у грудному та ранньому періодах життя дітей, народжених недоношеними, є: штучне вигодовування, порушення харчової поведінки, дихальні розлади, пасивне тютюнокуріння матерів, гіперплазія вилочкової залози.

Ключові слова: недоношені діти; клінічні детермінанти; пневмонія; сімейний лікар.

Вступ. Сезонне збільшення захворюваності на гострі респіраторні хвороби асоціюється з підвищеним запитом спеціалістів первинної ланки охорони здоров'я та населення щодо диференціально-діагностичного пошуку, верифікації діагнозу, адекватного оцінювання реальних ризиків і розробки тактики лікування $[7,10]$. У структурі дитячої захворюваності хвороби органів дихання становлять вагому частку, серед яких паренхіматозні ураження легень можуть бути причиною прогнозованої смертності малюків. Захворюваність на пневмонію становить на рік близько 15-20 на 1000 дітей перших трьох років життя і приблизно 5-6 випадків на 1000 дітей старше 3 років. Частота госпіталізації з приводу пневмонії у віці від 1 до 11 міс становить $29 \%$, від 1 до 5 років - $50 \%$, старше 5 років - $20 \%$, новонароджених - $1 \%[5,7]$. Летальність від пневмонії в різних регіонах України - від 1,5 до 6 на 10000 дітей [4].

За даними ВОО3, пневмонія залишається однією з основних причин дитячої смертності на всіх континентах і щорічно від неї помирають близько 1,8 млн дітей $[8,15]$. За даними європейських гадлайнів, має місце значне поширення захворювання в межах 33 на 100000 дітей у віці від 0 до 5 років і зменшення майже вдвічі до 14,5 - у віці від 0 до 16 років. Тяжкий перебіг пневмонії спостерігається у хлопчиків всіх вікових груп. У віці до 5 років у недоношених дітей 3 терміном гестації 24-28 тиж перебіг захворювання найтяжчий [11].

Важливим є також верифікація вроджених аномалій розвитку та спадкових захворювань бронхолегеневої системи: секвестрації (Q33.2), кість легенів (Q33.0), муковісцидозу (E84) [6].

Саме тому вчасне розпізнавання та ранній початок лікування, профілактичні заходи залишаються пріоритетними у розвитку сучасної педіатричної науки. Нині необхідний міжсекторальний підхід до лікувально-діагностичного процесу в умовах розвитку та становлення системи первинної медико-санітарної допомоги [7]. Для фахової успішності та покращання показників здоров'я лікар загальної практики сімейної медицини повинен бути інтегрованим у континіум терапевтичних, хірургічних наук та володіти віковими аспектами анатомо-фізіологічних, морфологічних особливостей і біохімічних процесів в органах і системах, зокрема дитячого організму.

Пневмонія асоціюється 3 лихоманкою вище $38,5^{\circ} \mathrm{C}$, інфільтративними змінами у легенях за даними рентгенографії, тахіпное [11-14]. Актуальний пошук простих, інформативних клініко-параклінічних детермінант верифікації діагнозу пневмонії у недоношених грудного та раннього дитячого віку. 
Мета дослідження - на підставі вивчення клініко-анамнестичних особливостей недоношених дітей грудного і раннього віку, використовуючи неоднорідну послідовну процедуру розпізнавання Вальда, визначити важливі клінічні детермінанти розвитку пневмонії для верифікації нозології респіраторного тракту на етапі первинної медико-санітарної допомоги.

Матеріали і методи. У міській дитячій лікарні Вінниці перебували на стаціонарному лікуванні у відділенні раннього віку діти основної клінічної $(n=13)$ та контрольної $(n=20)$ груп віком від 2 міс до 2,5 року, середній вік - 10,5 міс.

У групі дослідження хлопчиків було $54 \%$, дівчаток - $46 \%$, у контрольній групі - 55 \% хлопчиків і 45 \% дівчаток. Групу дослідження становили діти 3 верифікованим діагнозом відповідно до наказу МОЗ України № 18 від 13.01.2005 p. «Про затвердження Протоколів надання медичної допомоги дітям за спеціальністю «дитяча пульмонологія»», ураження легень. 5 дітей $(38,5$ \%) народилися в термін гестації (ТГ) 32-33 тиж 3 масою тіла $(1930 \pm 130)$ г, [min 1800 г; max 2060 г], 8 дітей $(61,5 \%)$ - в ТГ 34-36 тиж з низькою масою тіла при народженні $(2350 \pm 150)$ г, [min 2200 г; $\max 2500$ г]. Оцінка за шкалою Апгар на 1-й та 5-й хвилинах життя у $8(61,5 \%)$ дітей була в межах 5-7 балів, у 3 (23\%) - 7-8 балів, у $2(15,4 \%)$ - 8-9 балів. Отже, 11 (84,6 \%) дітей досліджуваної групи перенесли асфіксію різного ступеня тяжкості з відповідними реанімаційними заходами згідно 3 наказом МО3 України № 225 від 28.03.2014 р. «Початкова, реанімаційна i післяреанімаційна допомога новонародженим в Україні». В анамнезі у неонатальному періоді у $9(69,2$ \%) дітей діагностовано неонатальну жовтяницю, дихальні розлади (ДР) - у 5 (38,5 \%), гіпоксично-ішемічну енцефалопатію - у 7 (53,8 \%), морфофункціональну незрілість - у 10 (76,9\%); рис. 1.

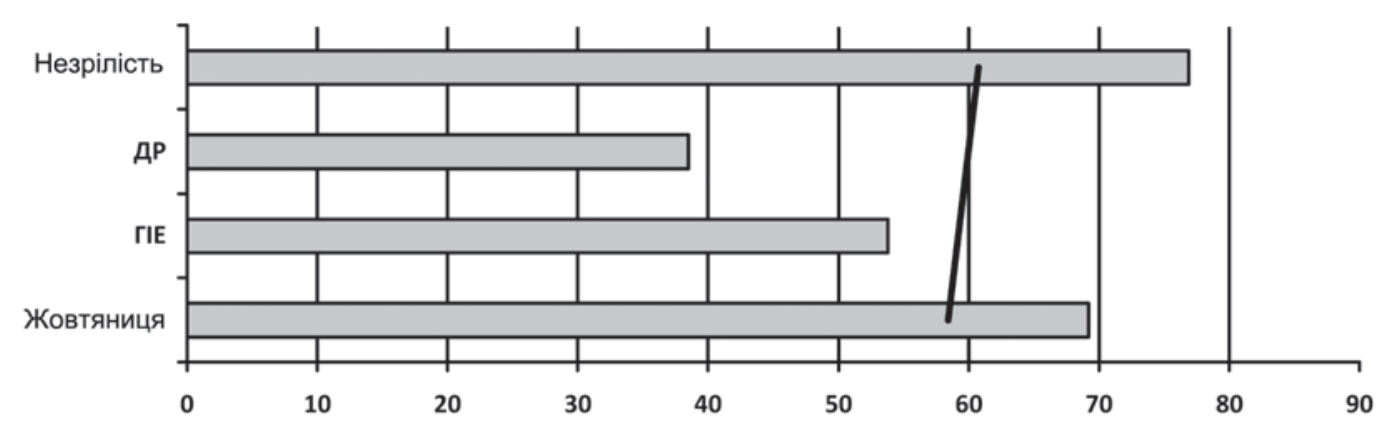

Рис. 1. Структура захворюваності дітей досліджуваної групи у неонатальному періоді

Таким чином, період новонародженості у дітей з низькою масою тіла в ТГ $\geq 32$ тиж відзначався поліморбідністю, на що вказує перевищення 100 \% структури захворюваності до скорегованого віку 44-46 тиж. 3 акушерського анамнезу відомо, що 4 (30,8 \%) дітей народилися за допомогою кесарського розтину, 9 (69,2 \%) - природним шляхом. Також виявлено проблеми обтяженого акушерського анамнезу у породіль, асоційовані з інфекційно-запальними та метаболічними порушеннями (рис. 2).

Троє (23\%) дітей народилися від матерів, у яких діагностовано невиношування вагітності та антенатальну загибель плода, 6 (46,2 \%) - від матерів з інфекційнозапальними захворюваннями - носійство Toxoplasma gondii $(15,4$ \%), пієлонефрит вагітних, безсимптомна бактерійурія $(30,8 \%), 1$ (7,7 \%) - від матері, хворої на цукровий діабет; 1 (7,7 \%) - від матері з артеріальною гіпертензією, 2 (15,4 \%) активно курили «легкі» цигарки у першій половині вагітності, при цьому 8 (61,5 \%) матерів зазнавали впливу пасивного тютюнокуріння. Таким чином, в акушерському анамнезі основної групи мали місце різні обтяжувальні фактори. Прикметним виявилося пасивне тютюнокуріння, що у підсумку сформувало мультифакторіальність та поширеність обтяжуючого акушерського анамнезу. 


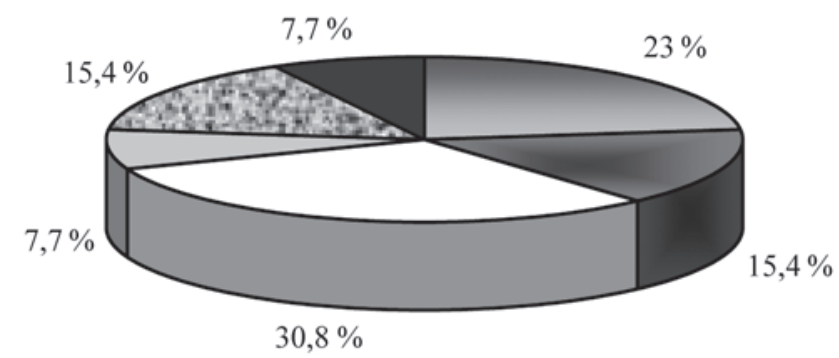

Рис. 2. Структура патології вагітності матерів дітей досліджуваної групи: $\square$ - невиношування, антенатальна загибель; $\square$ - носій Toxoplasma gondii; $\square$ - інфекційнозапальні захворювання; $\square$ - цукровий діабет; 5 - активне куріння; $\square$ - артеріальна гіпертензія

Дітей виписували на амбулаторний етап виходжування у задовільному стані із стабільними вітальними функціями (підтримка температурного гомеостазу, кардіореспіраторна діяльність, показники фізичного розвитку і харчова поведінка, що відповідала віку). Однак вигодовування лише грудним молоком збережено у 3 (23 \%) дітей, 10 (77 \%) отримували змішане, наближене до штучного і штучне вигодовування.

Контрольна група $(n=20)$ була сформована 3 пацієнтів, які отримували лікування з приводу гострих алергічних реакцій, функціональних розладів травлення, інфекції сечовидільних шляхів, відповідно до чинних стандартів діагностики та лікування відповідних нозологій. Всі діти народилися в ТГ 38-40 тиж з масою тіла вище 2500 г [min 2800 г; $\max 3450$ г], оцінка за шкалою Апгар на 1-й та 5-й хвилинах становила 8-9 балів, 3 (15\%) дітей народилися шляхом кесарського розтину, 17 (85 \%) - природним шляхом, отримували природне або змішане, наближене до природного вигодовування штучне вигодовування 2 (10\%) дітей.

Двадцять (62\%) дітей госпіталізовано вперше. 3 них на 2-й день захворювання - $3(10,4 \%)$, решта на 5-7-му добу захворювання; 38\% дітей були повторно госпіталізовані впродовж останнього року: 5 (15\%) - вдруге, 8 (23\%) - втретє, вчетверте. Причина повторних звернень - обструктивний бронхіт та бронхіоліт, токсико-алергічний дерматит, кропив'янка, гостре респіраторне захворювання.

У відділенні усім дітям, крім загальноклінічних обстежень, передбачених протоколами лікування, проведено ультразвукове дослідження вилочкової залози. Її розміри оцінювали за допомогою ультразвукового сканера Siemens Sonoline Adara 3 використанням конвексного (5 МГц) і лінійного (7,5-10 МГц) датчиків. Обчислювали лінійні параметри вилочкової залози - ширину, довжину і передньо-задній розмір і визначали об'єм залози з розрахунку на одиницю маси тіла дитини.

Використавши процедуру послідовного розпізнавання Вальда, на підставі ретельного аналізу клініко-анамнестичних даних та результатів додаткових досліджень у дітей основної клінічної і контрольної груп встановлено діагностичні коефіцієнти (ДК) і загальну інформативність клінічних детермінант (j), асоційованих з перебігом пневмонії у недоношених грудного і раннього дитячого віку в ТГ $\geq 32$ тиж. Знак (+) свідчить на користь інтактності, знак (-) - на користь ураження легеневої тканини. Інформативна міра $\mathrm{j} \geq 6$ свідчить про дуже високу інформативність виявленої клінічної ознаки, $6>\mathrm{j} \geq 1$ - високу, $1>\mathrm{j} \geq 0,5$ - помірну, $0,5>\mathrm{j} \geq 0,25$ - низьку, $0,25>\mathrm{j} \geq 0,1-$ дуже низьку.

Результати та їх обговорення. Блискавичний перебіг пневмонії з розвитком ускладнень та несприятливих наслідків у дітей грудного віку перш за все пов'язаний з асоціацією факторів ризику, що реалізуються у перинатальному періоді, та морфофункціональними особливостями функціонування дихальної i 
серцево-судинної системи, вікової індивідуальної реактивності дитячого організму, вірулентності збудника $[2,9]$. Так, найважливішими патогенетичними ланками розвитку паренхіматозного ураження легень $є$ перенесена асфіксія у поєднанні 3 внутрішньоутробним інфікуванням, що ініціює каскад біохімічних, гістофізичних змін у рамках реалізації системної запальної відповіді організму та порушення процесу онтогенезу безпосередньо легеневої тканини і серцеволегеневої адаптації в результаті генералізованої або часткової втрати вазомоторного тонусу легеневих судин з подальшою персистенцією фетального кровотоку в період новонародженості [10].

Поєднання цих процесів призводить до порушення дифузійних та перфузійних процесів у легенях на межі капілярно-альвеолярних мембран, що клінічно маніфестується ознаками дихальної недостатності. Слід відмітити також особливості будови стінки легеневих судин, які мають товсті стінки і вузький просвіт майже до першого півріччя (часточкові та сегментарні до року). Відносна вузькість і короткість бронхів та збіднений війчастий епітелій слизових оболонок трахеобронхіального дерева на фоні пухкого добре васкуляризованого підслизового шару дають можливість повністю проявитися та реалізуватися мікробним факторам агресії.

Разом 3 тим у грудному віці мають місце знижена імунореактивність $[1,3]$ та лімфогенний шлях поширення інфекції трахеобронхіальним деревом за рахунок особливостей будови лімфовідтоку від слизових оболонок дихальних шляхів.

Оцінюючи анамнез захворювання у дітей досліджуваної групи, важливими визначили такі клінічні детермінанти: перенесені критичні стани у період новонародженості (84,6 \%), морфофункціональну незрілість (77 \%), пасивне тютюнокуріння $(61,5 \%)$, відсутність природного вигодовування (77 \%), некоректне введення продуктів прикорму (15,3\%). Клінічно всі випадки легеневих захворювань (пневмонія різної локалізації і ступеня тяжкості) асоціювалися у 92,3 \% випадків 3 порушенням харчової поведінки і вегетовісцеральними розладами (зменшення об'єму споживання їжі, годування 3 перервами на відпочинок, відмова від їжі і пиття, зригування, здуття живота), у всіх випадках з дихальними розладами (тахіпное, ціаноз, участь допоміжної мускулатури в акті дихання, кашель, експіраторний стогін, $\left.\mathrm{SiO}_{2}<92 \%\right)$, у 38,5\% - 3 пригніченням, у $23 \%$ випадків - 3 гіпертермічною реакцією температури тіла (вище $38{ }^{\circ} \mathrm{C}$ ).

При додатковому інструментальному дослідженні (ультразвукове дослідження питомої ваги вилочкової залози) розміри вилочкової залози у дітей основної групи були більшими, ніж у дітей контрольної $\left(2,55 \mathrm{mM}^{3} / \kappa \Gamma \pm 0,09 \mathrm{MM}^{3} / \kappa г\right.$ проти $2,1 \mathrm{Mм}^{3} / \kappa \Gamma \pm$ $\left.0,09 \mathrm{Mм}^{3} / к г ; \mathrm{P}<0,05\right)$.

Найбільш значущі критерії розвитку захворювання такі: штучне вигодовування (ДК $-10 ; \mathrm{j} 8)$, ознаки дихальних розладів (ДК $-11,5 ; \mathrm{j} 6,04)$, пасивне тютюнокуріння (ДК $-8 ;$ j 5), порушення харчової поведінки (ДК $-6 ;$ j 7,59), тимомегалія (ДК $-4,5 ; \mathrm{j} 4,5)$.

Висновки. На підставі неоднорідної послідовної процедури розпізнавання Вальда визначено діагностичні коефіцієнти та інформативні міри значущих клінічних ознак перебігу пневмонії, що дає можливість лікареві первинної ланки диференціювати загрозливі для життя захворювання. Перспектива подальших досліджень полягає у пошуку і вивченні кореляційних зв'язків між встановленими клінічними детермінантами, ступенем тяжкості захворювання та віддаленими наслідками.

$$
\text { Спи сок л і те ратури }
$$

1. Булат Л. М., Лисунецьь О. В. Постнатальний онтогенез лімфоцитарно-гранулоцитарного ростка крові у дітей з малою масою тіла при народженні //Актуальні
1. Bulat L. M., Lisunec' O. V. Postnatal'nij ontogenez limfocitarno-granulocitarnogo rostka krovi u ditej z maloyu masoyu tila pri narodzhenni //Aktual'ni pitannya laborator- 
питання лабораторної діагностики та медицини сьогодення: Зб. матеріалів всеукр. наук.-практ. конф. - 2016. - С. 43-45.

2. Каракушикова А. С., Рахимова К. В., Абдулаева $Г . M$. Особенности иммунного статуса недоношенных детей с перинатальной патологией в раннем неонатальном периоде // Педиатрия. - 2012. - Вып. 91, № 1. - C. 20-23.

3. Лисунець О. В. Особливості імунного статусу у недоношених новонароджених високого перинатального ризику // Вісн. Вiнниц. нац. ун-ту. - 2012. - Вип. 16, № 1. C. 74-77.

4. Марушко Ю. В., Шеф Г. Г. Пневмонія // Дитячий лікар. - 2016. - Вип. 46, № 1. C. 5-25.

5. Майданник В. Г. Сучасні клінічні настанови діагностики і лікування пневмоній у дітей. - К., 2013. - С. 33.

6. Наказ МОЗ України № 18 від 13.01.2005 р. «Про затвердження Протоколів надання медичної допомоги дітям за спеціальністю “дитяча пульмонологія"»

7. Педіатрія: Підручник / За ред. В. В. Бережного.-К., 2013.-С. 207-232.

8. Сміян О. І., Бинда Т. П., Дмітрова Є. В., Сухарєва B. A. Сучасні етіопатогенетичні та клініко-діагностичні особливості перебігу гострих респіраторних вірусних інфекцій у дітей // J. of Clin. and Experiment. Med. Research. - 2013. - T. 1, № 3. C. 9-15.

9. Цимбаліста О. Л., Семкович Я. В., Семкович $М$. Я. Клініко-патогенетичний диференціальний підхід до діагностики пневмонії у дітей раннього віку, ускладненої гнійно-легеневим та токсичним синдромами // Галиц. лікар. вісн. - 2012. Вип. 19, № 1.- С. 85.

10. Щерба Ю. В., Гончарова И. В. Внебольничная пневмония в аспекте глобального процесса появления новых и возвращающихся инфекций: новые этиологические, эпидемиологические и клинические характеристики, приобретение категории системного инфекционного заболевания // Поликлиника. - 2011. - № 1. C. 215 .

11. British Thoracic Society guidelines for the management of community acquired pneumonia in children: update 2011 // Thorax jnl. - 2011. - Vol. 20, N 5. - P. 598.

12. Harari M., Shann F., Spooner V. et al. Clinical signs of pneumonia in children // Lancet. - 1991.Vol. 338. - P. 928-930.

13. Mahabee-Gittens E. M., Grupp-Phelan J., Brody A. S. et al. Identifying children with pneumonia in the emergency department // Clin. Pediatr. - 2005. - Vol. 44. - P. 427-435.

14. March M., Sant'Anna C. C. Signs and symptoms indicative of community-acquired pneumonia in infants under six months // Braz. J. Infect. Dis. - 2005. - Vol. 9. - P. 150-155.

15. Revised $W H O$ classification and treatment of childhood pneumonia at health facilities, evidence summaries. - Geneva: World Health Organization. - 2012. - http://www.who.int/maternal_ child_adolescent/documents/management_childhood_conditions/en materialiv vseukr. nauk.-prakt. konf. laeva G. M. Osobennosti immunnogo statusa nedonoshennyh detej s perinatal'noj patoiej v rannem neonatal'nom periode // $\mathrm{Pe}$ -

3. Lisunec' O. V. Osoblivosti imunnogo statusu u nedonoshenih novonarodzhenih visokogo un-tu. - 2012. - Vyp. 16, № 1. - P. 74-77.

4. Marushko Yu. V., Shef G. G. Pnevmoniya // Dityachij likar. - 2016. - Vyp. 46, № 1. diagnostiki i likuvannya pnevmonij u ditej. K., 2013. - P. 33

«Pro zatverdzhennya Protokoliv nadannya medichnö dopomogi dityam za special'nistyu "dityacha pul'monologiya"»

. Pediatriya: Pidruchnik/Za red. V. V. Berezh- K.,2013 - P. 207-232.

Suhareva $V$. A. Suchasni etiopatogenetichni ta kliniko-diagnostichni osoblivosti perebigu gostrih respiratornih virusnih experiP. 9-15.

vich M. Ya. Kliniko-patogenetichnij diferencial'nij pidhid do diagnostiki pnevmoniï u ditej rann'ogo viku, uskladnenoï gnijno-legenevim ta toksichnim sindromami // Galic. likar. visn. - 2012. - Vip. 19, № 1. P. 85.

bol'nichnaya pnevmoniya $\mathrm{v}$ aspekte glovozvrashchayushchihsya infekcij: novye

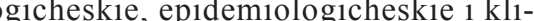
gorii sistemnogo infekcionnogo zabolevaniya // Poliklinika. - 2011. - № 1. - P. 215. noi diagnostiki ta medicini s'ogodennya: $\mathrm{Zb}$. bal'nogo processa poyavleniya novyh i 
ДИАГНОСТИКА ПНЕВМОНИИ У НЕДОНОШЕННЫХ ДЕТЕЙ ГРУДНОГО И РАННЕГО ВОЗРАСТА В ПРАКТИКЕ СЕМЕЙНОГО ВРАЧА

\section{О. В. Лисунеи, Н. В. Дидык (Винница)}

Поскольку патология дыхательной системы занимает ведущее место в структуре заболеваемости детского возраста, поиск новых теоретических данных и распространение клинического опыта способствует профессиональному росту врачей-педиатров и врачей общей практики семейной медицины. Очень важным является налаживание врачебного сопровождения и сохранение профессиональной бдительности относительно наблюдения за детьми грудного и раннего возраста. В особенном внимании нуждаются преждевременно рождённые дети, поскольку часто симптомы морфофункциональной незрелости и неврологических нарушений не позволяют вовремя определиться с соматической патологией, что приводит к потере времени и промедлению с установлением клинического диагноза. Вместе с тем количество детей, которые рождаются преждевременно, остаётся в пределах $5 \%$, что требует адекватной и корректной тактики вмешательства врачей первичного контакта. Распространяя опыт наблюдения и лечения младенцев и детей раннего возраста, авторы стремились определить характерные признаки течения этих периодов у преждевременно рождённых детей и выяснить наиболее весомые симптомы и анамнестические данные, которые ассоциирувались с манифестацией инфекционно-воспалительного поражения лёгких и определить их диагностические коэффициенты (ДК) и общую информативность вышеуказанных клинических детерминант (j). Были проанализированы данные наблюдения за недоношенными детьми основной группы с верифицированным, в соответствии с отечественными стандартами диагностики и лечения, паренхиматозным поражением лёгких и контрольной группы. В статье описаны клинико-анамнестические особенности течения пневмонии у недоношенных грудного и раннего возраста детей, рождённых в сроки гестации $\geq 32$ нед. Установлены важные клинические детерминанты, способствующие верификации диагноза семейным доктором. Указаны изменения в органах и системах, которые ассоциируются с пневмонией у недоношенных детей. Важнейшие клинические детерминанты развития пневмонии: искусственное вскармливание, нарушение питания, дыхательные расстройства, пассивное табакокурение, гиперплазия вилочковой железы.

Ключевые слова: недоношенные дети; клинические детерминанты; пневмония; семейный доктор.

\section{DIAGNOSTICS OF PNEUMONIA IN PRETERM INFANTS OF THE BREAST-FEEDING AND THE PRE-PRESCHOOL PERIOD OF THE LIFE IN THE PRACTICE OF FAMILY DOCTOR}

\section{O. V. Lysunets, N. V. Didyk (Vinnytsya, Ukraine)}

National Pirogov Memorial Medical University, Vinnytsya

Diseases of the respiratory system are important causes of children's morbidity. That is why we suggest that the spreading of the clinical experience is helpful for the pediatric community to improve the practical skills and theoretical knowledge of the physicians. The article describes clinical and anamnestic peculiarities of run of period of the breast-feeding age and pre-preschool age at a preterm newborn with a small body weight at birth with a period of gestation of 32-36 weeks and infants of 38-40 weeks of gestation. Taking into account the anatomical and functional features of premature infants, they need of a multidisciplinary approach in order to care and treat them. The important anamnestic determinants that can point possible the later complication are the interrupted pregnancy and incompetent pregnancy, harmful habits (the active and pasive smoking) of gravids and their infectious diseases (kidney disorders) and no-infectious diseases like diabetes mellitus and arterial hypertension. Actually, a physician has to know many various combinations of symptoms and syndromes, which are characteristic for the preterm infants. The article includes clinical and anamnestic patterns of motion of pneumonia in infants with a period of gestation of 32-36 weeks in the breastfeeding and the pre-preschool period of the life. The important clinical determinants that can be used for diagnostic search of family doctor have been determined. The changes in organs and systems associating with development of pneumonias in the preterm infants have been displayed. The most important the clinical determinants of development of pneumonia are the artificial feeding, the violation of feeding and composition of food, disturbance of respiration, the smoking, hyperplasia of the thymus. The main idea of our article is that the most cases of morbidity premature infants depends on immature of internal organs, immune system and development of the infection complication. The main "take-away lessons" are that premature infants should be observed a long time after disease. Conclusions: premature infants need a multidisciplinary approach in order to care and treat them.

Key words: preterm infants; clinical determinants; pneumonia; a family doctor. 